\title{
Relationship between Dividend Policy and Share Price
}

\author{
NTUI Ponsian \\ Accountancy and Finance Lecturer \\ St. Augustine University of Tanzania \\ Kawiche Prosper \\ Accountancy and Finance Lecturer \\ St. Augustine University of Tanzania \\ Thadeo Yuda \\ Accountancy and Finance Lecturer \\ St. Augustine University of Tanzania \\ Godfrey Samwel \\ Bachelor of Business Administration \\ St. Augustine University of Tanzania
}

\begin{abstract}
The study aims to examine the relationship between dividend policy and share price for companies listed on Dar Es Salaam Stock Exchange (DSE). The investigation is based on the listed companies for the period of five years from 13 companies where the data is extracted from the company's annual reports. This is measured by dividend policy operationalized by four variables including Dividend Yield, Dividend Payout Ratio, Earnings Per Share and Price Earnings (P/E) ratio. The study is quantitative in nature where the SPSS is applied as tool of analysis by using descriptive, regression and correlation methods to measure the relationships. The results show that the best dividend policy measure is price earnings $(P / E)$ ratio as indicated by the lowest $P$ value and relationship between dividend policy and share price is that; dividend payout ratio, earnings per share and price earnings ratio have positive relationship while dividend yield is negatively related to share price.
\end{abstract}

Keywords: Dividend policy, Share price, Dar Es Salaam Stock Exchange, Tanzania

\section{INTRODUCTION}

The purpose of this study is to investigate the relationship between dividend policy and share price. In economical circumstance many financial experts and investors are concerned about dividend policy of the companies. Dividend policy is the most debated topic among the researchers. It is discussed by different people in different areas which cause misunderstanding between themselves about dividend policy and share price relationship to maximize the shareholders wealth. Many theories and models are provided for investigating relationship of this study.

There are more than five theories which are relevance theory, irrelevance theory, signaling theory, tax-effect hypothesis, clientele effect of dividend and agency theory which are discussed to show the significance of this study. From these theories it was found that, there is 
a group of researchers who agree on the relationship and other researchers who disagree on the relationship between dividend policy and share price.

In 1961 miller and Modigliani came up with dividend irrelevancy theory to show that there is no relation between dividend policy and share price. They regard only effect on ordinary income and capital gain but not in the total gain of the shareholder and give some assumptions such as no tax is charged, no transaction cost and no cost of contract. But in 1962 (Gordon and Linter) disagreed on the theory and the assumptions provided by Miller and Modigliani in 1961 when came up with the dividend relevancy theory which agrees the relationship between dividend policy and share price to raise the shareholder wealth. The Gordon and Linter said that the investors prefer more dividend payment rather than capital gain.

The other researchers such as Baker and Powell in 1990 agree with relationship, also watts, $\mathrm{R}$ in 1973 come up with positive answer that the relationship exists. All those researchers use the listed companies in their geographic location to prove relation by using the different measurements of dividend policy to investigate the relationship by using linear regression and correlation models.

Though in real terms it is shown that there is no relationship between dividend policy and share price theoretically but practically the relation exists and in the company with higher dividend payout ratio the investors invest for the purpose of profit maximization.

The problem of existing relationship between dividend policy and share price is not only found to be a challenge in Tanzania but also throughout the world. This problem existed for long time and continues to exist in economic circumstances. The problem of dividend policy and share price has brought so many contradictions to different researchers from different countries. However the studies from different parts of the world focused on dividend policy in relationship with share price volatility instead of share price. From these studies it is also shown that there is no single measure of dividend policy. Therefore the aim of this study is to find out the relationship between dividend policy and share price focusing on dividend relevancy theory. This will therefore give us the best dividend policy measure which is not clearly shown in all studies.

\section{LITERATURE REVIEW}

Dividend policy and share price is the area of study where various scholars have written and come up with contradicting results. This chapter exposes the results and conclusions from various studies in different countries in the world to establish knowledge gap. The chapter is arranged to review, relation between dividend yield and share price, relations between dividend payout and share price, relations between earnings per share and price earnings ratio on share price.

\section{Relation between Dividend Yield and Share Price}

According to Suleiman (2011) share price volatility has significant positive relationship with dividend yield. This was concluded by extracted data from Karachi Stock Exchange regarding five important sectors for the period of 2005 to 2009 where multiple regressions model for analysis was used.

According to Nazir at all (2010) dividend yield has significant effect on stock price. The study explains the determinants of stock price volatility in Karachi stock exchange by using a sample of 73 firms taken from the KSE 100 index companies of different sectors. The data is collected 
from the balance sheet published by state bank of Pakistan and annual reports of the companies. Price volatility is taken as dependent variable, dividend yield and payout ratios are taken as independent variables. They used descriptive and correlation matrix to find the results. Okafor and Mgbame (2011) conducted a study to analyse dividend policy and share price volatility in Nigeria by taking sample of 4 banks and 2 firms each from food and beverage, petroleum and brewing sectors. Stock and financial related data of these firms are collected over 8 years period. Major source of data collection is annual fact book of Nigerian stock exchange, dependent variable is price volatility and independent variables are dividend yield, payout ratio, assets growth and earnings volatility. The relationship between ordinary stock price volatility and dividend policy has been analyzed by using regression. The result of their study show that general effect of dividend yield on price volatility observed at higher significant level.

Dividend yield and share price are positively related, Habib et al, (2012). Habib et al. conducted study about dividend policy and share price volatility evidence from Pakistan. To draw and establish relationship between dividend policy and shareholder volatility with focus on Pakistani stock exchange, dividend yield, payout ratio, size, debt, earning and growth are independent variables and share price volatility is a dependent variable. Cross sectional regression was used to analyze relationship of share price with dividend yield and payout ratio.

Zulkifli et al. (2012) in their study showed the impact of dividend policy in share price volatility in construction and material companies of Malaysia. A sample of 106 construction and material companies and 77 construction and material companies for the period of six years was selected. Share price volatility as the dependent variable and dividend yield dividend payout ratio, leverage, growth, size and earnings volatility as the independent variables were used. Least square regression models are used to interpret the results of this study. The results show that the dividend yields have positive effect on the share price.

According to Asghar at al. (2011) share price volatility has strong positive correlation with dividend yield. This is shown on the study about the effect of dividend policy on share price by collecting data for five important sectors i.e., chemical, cement, sugar, engineering, synthetic \& fiber for the period of four years. Data were from the published resources of state bank of Pakistan and Karachi stock exchange and regression model based on Baskin (1989) documentation was used to conclude the results.

It is expected that share price volatility is being affected negatively by dividend yield, but the top review explained that there is positive impact of dividend yield on share price volatility based on; the duration effect, the rate of return effect, the arbitrage effect and the information effect. These results derive us to hypotheses that:

\section{H1: There is a positive significant association between share price and dividend yield}

\section{Relationship between Dividend Payout and Share Price}

According to Nazir et al. (2010) share price significantly influences dividend policy as measured by dividend payout ratio and dividend yield. The study used 73 firms listed on Karachi Stock Exchange (KSE-100) indexed.

Barker and Powell surveyed 603 chief financial officers of US firm listed on New York stock exchange and observed that $90 \%$ of the total respondents believed that dividend payout policy positively affects a firm's value and therefore shareholders wealth. 
Dividend payout is by far the single important factor affecting stock prices, Sen and Ray (2003). So the study explored one of the crucial factor i.e. dividend payout ratios having impact on Indian stock price. The authors have explained an interesting phenomenon regarding the key determinants of stock price in India based upon the stocks comprising the BSE index over a period 1988-2000.

Gordon (1959) supports the bird in the hand theory. The researcher generates dividends and earnings data of four industries namely chemicals, foods, steels, and machine tools for year 1951 and year 1954. He then employed a linear regression methodology to examine the relationship between share prices and dividends/ retained earnings. The results show that dividends have a greater impact on share price than retained earnings do, and the required rate of return has a positive correlation with the fraction of retained earnings. In other words, dividends are preferred to capital gains because of their certainty. Similar results are found by Fisher (1961), who conducted the empirical research based on the British data generated for the period between year 1949 and year 1957.

In their study, Mokaya and James (2013) explain how dividend policy effect share price in banking industry of Kenya. This study covered the sample of 100 respondents represented a population of 47000 general public shareholders and questionnaires were used to collect the data. Market share value is the dependent variable and dividend policy is the independent variable. Descriptive and inferential statistics were used to determine and explain variable's relationships. The study concluded that National Bank of Kenya had a dividend policy and this dividend policy is the major factor driving NBK share value. It has been seen that an increase in dividend payout may result an increase in share price.

The five researchers such as Nazir, Mokaya. And James, Sen. and Ray (2003), Barker and Powell and others explained about impact of dividend payout on share price volatility based on the rate of return they come up with positive relationship. They argue that divided pay out can be used as an alternative for predicted growth and investment opportunities so that firms with higher dividend payout have higher share price. They also explained that high dividend payout can be interpreted as stability of a firm and reduce the fluctuation in share price of that firm. These results of researchers show that the conclusion of the hypothesis is:

\section{H2: There is a positive significant relation between share price and payout ratio.}

\section{Relation between Earnings per Share, Price Earnings Ratio and Share Price}

Empirical findings show that dividend per share and price earnings ratio influence positively by share price, Nirmala and Sanju (2011). The study focuses on three sectors viz., auto, health care \& public sector undertakings over the period 2000-2009. They employed panel co integration test and fully modified least squares to examine the effect of dividend, profitability, price earnings ratio and leverage on share prices.

Sharma (2011) shows the results that earning per share, dividend per share and book value per share has significant impact on the share price of different industry groups in India when examined companies in the period of 1993- 2008 in different industries group.

Disclosures of forecasts of earnings per share were accompanied by significant price adjustments, from which the inference may be drawn that either the data presented in a management forecast, the act of voluntary disclosure, or both convey information to investors. 
Subsequent price behavior was relatively low for the positive forecast group and continued to decline for negative forecast group Patell (1976). The researcher test considers weekly data of 258 firms listed with NYSE for the period of 1963 to 1967. Researcher took 336 observations for testing.

According to Beaver (1968) the findings indicate that reported earnings per share are associated with underlying events that are perceived by investors to affect the share price and the study was based upon a sample of annual earnings announcements released by 143 firms listed in NYSE during the years 1961 through 1965. These arguments make us to hypothesize:

\section{H3: There is a positive significant relation between earnings per share, price earnings ratio and share price}

\section{Knowledge Gap}

Different researchers in the world have done research in trying to find out relationship between share price volatility and dividend policy. There is a little research on share price and dividend policy. The results are different from the companies or institution they choose to conduct the research, methodology used by researcher and the economic level of their countries. Differences may be due to the level of economy that to say the research conducted to the higher developed capital market rather than less developed capital market with only 18 companies listed. The other researcher does not make consideration on less developed countries when they conduct study and also make generalization to conclude the study and fail to provide answer in all levels of economy. Also all studies used multiple measure of dividend policy and there is no single study showing the best measure of dividend policy. The study is conducted in Tanzania companies because the level of economy in terms of market is poor in order to show what it is not done by other researchers. Therefore this study finds out the relationship between dividend policy and share price and also finds out the best dividend policy measure.

\section{METHODOLOGY}

Quantitative approach is used from data collection to the analysis. Quantified data were collected to meet the appropriate conclusions at the end of study. The researcher collected total earnings, total dividend, share price, net earnings income, preference dividend and number of shares from annual reports and websites of the listed companies and analyze the data by using descriptive analysis, linear regression analysis and for the strong relationship we used correlation analysis in the SPSS.

\section{Data Collection}

The study used the data from 13 listed companies' annual reports, websites, organization records and companies' reports. The collected data were operationalized to be in ratio form as used in the analysis. The extracted data from the records were treated as primary information as they were not prepared for that purpose. These were: dividend, dividend per share, market share price, earnings, number of shares, and book value of shares. These then were computed to be in form of ratios where they were not readily available. Where ratios were there already, the same were collected.

\section{Population and Sample Size}

The target population was 18 listed companies on DSE and their audited financial statements in order to get the all data for analysis and to come up with the complete conclusion to make decision. The sample taken from the listed companies is 13 companies out of 18 companies on Dar es Salaam stock exchange for the period of 5 years from 2007 to 2011 . The sample of 13 companies is due to the fact that only 13 companies had five years information needed for the 
study. Some companies are young in the market and others lack information for the purpose of study.

\section{Model Specification}

Panel data was used to analyze the relationship between dividend policy and share price. Descriptive statistics and multiple regression analysis were used to analyze the results. Regression model was used to show the relationship between dividend policy and share price as follows:

Regression analysis model

$$
\text { P.vol }=\beta 0+\beta 1(\text { D.yield })+\beta 2(D P R)+\beta 3(P / E)+\beta 4(E . v o l)+\alpha
$$

Where:

Dividend yield (D.yield) is calculated by summing all the annual cash dividends paid to common stock holders and then dividing this sum by the average market value of the stock in the year.

Dividend payout ratio (DPR) is the ratio of total dividends to total earnings.

Price earnings ratio $(\mathrm{P} / \mathrm{E})$ means price to earnings ratio. That is, current share price divided by the current earnings per share.

Earnings per share (E. vol) means earnings per share and is calculated by taking the net income less preference dividends divided by number of shares

P. vol is the share price and $\beta 0$ $\beta 4=$ coefficients

\section{Analysis}

Regression analysis is used to estimate the causes of relationships between dividend payout ratios, dividend yield, price earnings ratio, earnings per share on share price. The research used correlation models, specifically Pearson correlation to measure the degree of association between dividend policy and share price. The study uses quantitative analysis because the method of analysis such as regression and correlation are used to measure the validity degree between dividend policy and share price. The researcher is able to identify many important variables associated with dividend policy and to formulate model regarding to those variables. Descriptive statistics were also used to know mean, variance, and standard deviation, minimum and maximum variables.

\section{FINDINGS}

The purpose of this chapter is to present analysis and interpret the findings. The presentations, interpretation of the findings are focused on the research objectives that are used in the study. Findings are arranged in the order to answer all objectives or relationships intended in the study.

\section{Descriptive Statistics}

Descriptive analysis shows the average and standard deviation of the different variables of interest in the study. It also presents the minimum and maximum values of the variables which help in getting a picture about the maximum and minimum values a variable can achieve. 
Table 1 present's descriptive statistics for 13 Tanzania financial and non financial firms for a period of five years from 2007 to 2011 making a total of 65 firms' observations.

Table 1

\begin{tabular}{|l|c|c|c|c|}
\hline Variable Name & Minimum & Maximum & Mean & Std. Deviation \\
\hline P. vol & 150 & 13160 & 2454.26 & 3031.008 \\
\hline DPR & -0.96 & 1.44 & 0.4049 & 0.30974 \\
\hline P/ E ratio & 3.29 & 582.47 & 46.1034 & 133.85086 \\
\hline D. yield & 0.01 & 0.19 & 0.0691 & 0.04749 \\
\hline E.vol & -84.00 & 765.03 & 1.390600 & 171.98232 \\
\hline
\end{tabular}

The results show that the P. vol has larger expected value of Tshs 2454.26 compared to those independent variables such as $\mathrm{D}$ yield had lowest mean value of 0.0691 , dividend payout ratio lower mean value of 0.4049 , price earnings ratio of 46.1034 and E. vol is 1.390600. The expectation is away from provided relation among the variables because the independent variables are lower than dependent variables. P. vol also has highest standard deviation of 3031.008 while the D. yield has lowest standard deviation amongst others variable with value of 0.04749 this implies that the low standard deviation data points tend to be very close to the expected value with low risk and a high standard deviation indicates that the data points are spread out over a large range of values with very high risk. Moreover the P. VOL has wider range of 13010 (maximum- minimum) as dependent variable while the D. yield has lower range amongst variable with value of 0.18 among other independent variables.

\section{Regression Analysis}

The regression statistics of the variables which are used in this research are represented in Table2. It indicates Standardized coefficient, t- statistic, Standard error and Significance of both dependent and independent variables.

Table 2

\begin{tabular}{|l|l|l|l|l|l|}
\hline Variable & $\begin{array}{l}\text { Un-standardized } \\
\text { coefficient }\end{array}$ & $\begin{array}{l}\text { Standard } \\
\text { error }\end{array}$ & $\begin{array}{l}\text { Standardized } \\
\text { coefficient B }\end{array}$ & t- statistic & Sign. \\
\hline (constant) & 1505.423 & 414.904 & & 3.628 & 0.001 \\
\hline DPR & 589.627 & 678.614 & 0.060 & 0.869 & 0.388 \\
\hline P/E ratio & $20.130^{*}$ & 1.523 & $0.889^{*}$ & 13.218 & 0.000 \\
\hline D. yield & $-8460.396^{* * *}$ & 4689.210 & $-0.133^{* * *}$ & -1.804 & 0.076 \\
\hline E.vol & & & & $150^{* *}$ & 2.102 \\
\hline
\end{tabular}

$\left.{ }^{* * *}\right)\left({ }^{* *}\right)(*)$ significant at $10 \%, 5 \%$ and $1 \%$ respectively

$\mathrm{R}=0.768$; Adj. R-square 0.753 Std.error estimate 1507.222

The Share price is taken as dependent variable and used in a regression of four independent variables namely dividend payout ratio, dividend yield, price earnings ratio and earnings per share. The relationship between share price and dividend yield is negative and significant. This means that the companies with negative D.yield there is loss earning on what invested by 
investors and also the higher the share price the lower the D.yield. The results support the findings by Hussainey et al. (2011) who claim that firms with higher dividend yield have lower share prices. The table also shows that the dividend payout ratio has positive coefficient but not significant related with share price. The other independent variable E.vol has positive significant impact on share price. This means that the higher the share price the higher the E.vol and also company which generates more profit are able to pay back the shareholder on what they invested. The last independent variable is $\mathrm{P} / \mathrm{E}$ ratio and has positive significant relationship with share price and has a maximum t-value on share price to be greatly influenced by price earnings ratio.

\section{Correlation Statistics}

Table 3 represents correlation among the variables to check the relationship they have between them. The correlation analysis is observed on the 65 observations of financial information from the 13 companies from the year 2007 through 2011.

Table 3

\begin{tabular}{|c|c|c|c|c|c|}
\hline & P. Vol & payout ratio & $\mathrm{P} / \mathrm{E}$ ratio & D. yield & E. vol \\
\hline P. Vol & 1 & & & & \\
\hline DPR & $-0.269 * *$ & 1 & & & \\
\hline $\mathbf{P} / \mathbf{E}$ & 0.864* & $-0.354^{*}$ & 1 & & \\
\hline DY & $-0.222^{* * *}$ & $0.334^{*}$ & -0.203 & 1 & \\
\hline E. vol & -0.085 & 0.198 & -0.207 & $0.473^{*}$ & 1 \\
\hline
\end{tabular}

$\left(^{*}\right),\left({ }^{* *}\right),\left({ }^{* *}\right)$ significant at $1 \%, 5 \%$ and $10 \%$ level

The table shows that the dividend payout ratio and share price have negative significant correlation of 0.269 at $5 \%$ level. Also dividend yield and share price show the same result as payout. The Correlation coefficient of D.yield is negative and significant with 0.222 at $10 \%$ level. The correlation results between earning per share and share price give the same answer with the negative correlation coefficient of 0.085 but not significant. But only one variable shows the positive significant correlation with share price which is price earnings ratio of 0.864 at level of $1 \%$. The result shows that the higher the D.yield, Payout and E.vol the lower the share price. It may be the companies are small and growing up but only one variable is positive related to the share price. The implication is that the higher the $\mathrm{P} / \mathrm{E}$ ratio the higher the share price meaning that the companies are able to pay back to the investors.

\section{The Best Dividend Policy Measure}

From Table 2, $\mathrm{P} / \mathrm{E}$ is concluded to be the best dividend policy measure because it has the lowest $\mathrm{P}$ value followed by earning per share and lastly the dividend yield. Dividend payout ratio is not a good dividend policy measure because it has the highest $\mathrm{P}$ value as compared to other measures in this study.

If the $\mathrm{P} / \mathrm{E}$ is taken to be the best dividend policy measure the relationship between share price and dividend policy is positive and highly significant at $1 \%$ hence the dividend irrelevant theory in business has no room. The findings clearly show that dividend policy has significant influence or relevance to the share price. 


\section{DISCUSSION}

Dividend policy of companies seems to influence change of share price practically but theoretically it raises different views and result among researchers. The findings of this research help to add value to the discussion as it links the findings with literature in order to provide understandable interpretation and conclusion.

The results for three variables measuring dividend policy are consistent with the literature by showing positive relationship with share price and there is only one variable showing the negative relation with share price. The independent variable P/E ratio, Payout and E. vol show positive relationship with share price and this is consistent with body of literature. D. yield brings contradicting results toward the share price meaning that the higher the D. yields the lower the share price. Though D. yield contradicts the literature, the result is in line with Hussainey et 2011, Uddin and Chowdhury 2005, Nazir et al 2010 and Allen and Rachim who show that price volatility is negatively related to D. yield. The last independent variable (P/E ratio) shows the positive significant relationship with share price. The higher the P/E ratio the higher the share price, the result is in line with the Nirmala and Sanju (2011), Sharma (2011), Patell, J. M. (1976), Beaver, (1968) who indicate that higher $\mathrm{P} / \mathrm{E}$ ratios in companies are associated with higher share prices. It is this study which shows that P/E ratio is the most highly significant indicating that it may be the best dividend policy measure.

\section{CONCLUSION}

The study shows that dividend payout ratio has positive relationship with share price though not significant. This implies that the higher DPR may result to higher share price though at a small increment. Similarly price earnings ratio and E.vol has a positive and highly significant relationship with share price indicating that the higher the price earnings ratio and dividend per share the higher the share price. This may also mean that companies with higher P/E ratio and E.vol have higher share prices. In contrary D.yield shows a negative relationship with share price indicating that companies with higher D.yield has lower share price.

The results show that share price is highly influenced by the dividend policy. P/E is concluded to be the best dividend policy measure because it has the lowest $\mathrm{P}$ value followed by earning per share and lastly the dividend yield. Dividend payout ratio is not a good dividend policy measure because it has the highest $\mathrm{P}$ value as compared to other measures in this study.

Generally in the today's complex world of business the dividend irrelevance theory seems to be of no importance due to the fact that its assumptions are not realistic as personal or corporate income taxes exist, there are stock flotation or transaction costs, financial leverage does affect the cost of capital, managers and investors have access to the different information concerning firm's future prospects, firm's cost of equity is affected in any way by distribution of income between dividend and retained earnings and dividend policy has impact on firm's capital budgeting.

\section{Reference}

Abdul R. R., Yaacob, M. H., Alias, N. and Mat nor, F. (2010), Investment, Board Governance and Firm Value: A Panel Data Analysis, International Review of Business Research Papers, Vol. 6 (5), pp. 293- 302

Adjaoud, F. and Ben-Amar, W. (2010), corporate governance and dividend policy: shareholders' protection or expropriation, Journal of Business Finance \&Accounting, Vol. 35, (5), pp 648-667.

Afzalur, R. A. and Anisur R. A. Z. M. (2008), Dividend Policy and Stock Price Volatility: Evidence from Bangladesh, Journal of Applied Business and Economics 
Ponsian, N., Prosper, K., Yuda, T., \& Samwel, G. (2015). Relationship between Dividend policy and Share Price. Archives of Business Research, 3(3), $11-20$.

Ahmed, H. and Javid, A. (2009), Dynamics and determinants of dividend policy in Pakistan: evidence from Karachi stock exchange non-financial firms, International Research Journal of Finance and Economics, Vol. 25, pp. 148-171

Allen, D. E and Rachim, V. S. (1996), Dividend policy and stock price volatility: Australian evidence, applied financial economics, Vol. 6. 175-188

Asquith, P and D millins (1983), the impact of initiating dividends on shareholder wealth Journal of business, Vol. 56, pp. 77-96

Aviation, V. A., Booth, L., and Cleary, S. (2006), Dividend Smoothing and Debt Ratings, Journal of Financial and Quantitative Analysis, Vol. 41 (2)

Chen, J. and Dhiensiri, N. (2009), Determinant of dividend policy: the evidence from newzealand, International research journal of financial and economics, Vol. 34, pp 18-28

Downs .T. W., (1991), an alternate approach to fundamental analysis: The asset side of the equation, Journal of portfolio management, Vol. 17(2), pp 6-17

Fama.E. F (1991), Efficient Capital market II, Journal of finance, Vol. 46, September 15. 75-617

Harry, F. and Steven, A. (1994), Statistic concepts and application, Cambridge, Cambridge University press P1 13

Hashemijoo, Mohammad, Mahdavi, A. Ardekani and Younesi Nejat (2012), Valuation of shares, Journal of business studies Quarterly, Vol. 4 (1)

Lee, E. J et al. (2009), How corporate governance affects payout policy under agency problems and external financing constraints, Journal of Banking \& Finance, Vol. 33, pp. 2093-2101

Mokaya S, Nyangara D and James L, (2013), "The effect of dividend policy on market share value in banking industry: the case of national bank of Kenya" International journal of arts and commerce Vol. 2(2)

Muhammad Asghar (2011), "The impact of dividend policy on stock price risk: Empirical evidence from equity market of Pakistan" Journal of psychology and business, Vol. 4 (1)

Suleman, M. Asghar, M. Ali shah, S. and Hamid, K. (2011), Impact of dividend policy on stock price risk: empirical evidence from equity market of Pakistan.

Uddin, M. H and Chowdhury, G. M. (2005), Effective of dividend announcement on shareholders' value: Evidence from Dhaka stock exchange, Journal of business research, Vol. 34. pp 433-441

Zulkifli et al. (2012), the impact of dividend policyon the share price volatility" International journal of economics and management science Vol. 2 (5), pp 01-08 